\title{
Legal Protection of Breeder Rights and Farmer Rights concerning Protection of Plant Varieties
}

\author{
Elsya Lucia Gracella ${ }^{1}$, Budi Santoso ${ }^{2}$, Edy Sismarwoto ${ }^{3}$ \\ \{elsyalucia08@ gmail.com ${ }^{* 1}$, budisantosotmg@ lecturer.undip.ac.id ${ }^{2}$, \\ edy_sismarwoto@live.undip.ac.id ${ }^{3}$ \}
}

Fakultas Hukum, Universitas Diponegoro, Jl. Prof. H. Soedarto, S.H., Semarang, Indonesia 50275 1, 2, 3

\begin{abstract}
Plant Variety Protection (PVT) is a part of Intellectual Property Rights (IPR) which is highly needed in agriculture in Indonesia. Regulations on the Protection of Plant Varieties are contained in Law No. 29 of 2000 concerning Protection of Plant Varieties. The drafting of the PVP Act should protect the rights of breeders (Breeder's Rights) and may not damage the farmers' privileges (Farmer's Privilege). However, there are still cases regarding the Protection of Plant Varieties which in their settlement do not use the PVP Law. This study uses normative juridical methods with qualitative analysis. The data in this study are secondary data obtained from primary, secondary and tertiary legal entities. Furthermore, these data are analyzed using qualitative data analysis methods. The results showed that the regulation of PVP in the PVP Law in Indonesia is still unclear and balanced in regulating between Breeder's Rights and Farmer Rights. It is also known that there are still many plant breeders who have not yet registered plant varieties for their breeding, due to the complexity and high cost of PVP registration.
\end{abstract}

Keywords: Breeder's Rights, Farmer's Rights.

\section{Introduction}

The era of globalization, marked by increasingly intense competition in various fields of activity, as is happening today, can lead to ambivalence for a nation and state. On the one hand, it can be advantageous if the nation and country have adequate readiness to compete with other nations and countries.

The agriculture sector in Indonesia is one of the fields that can be developed as a means to be actively involved in international trade, bearing in mind that agricultural products are export commodities that are urgently needed in various foreign countries. This can be realized when all components of this nation are united in building a strong agriculture and are able to compete with the agricultural products of other countries, both in terms of quality and price. Conversely, if there is no commitment to develop resilient agriculture, Indonesia can instead become a market for agricultural products from other countries. This has happened in recent years. The life of a resilient agricultural sector will be the foundation for the Indonesian people to carry out development in other sectors. [1]

Meanwhile, the rapid development in the economic, social and food technology sectors has caused food problems to become problems of a global dimension. Science and technology in the field of food have advanced rapidly, so that the problem is not only focused on food products that can be used as a potential commodity for increasing income of the community 
and the state, but also on the source of food production itself that can be engineered such as the creation of plant varieties which can produce superior products.[1]

In Indonesia, the ability to produce new varieties, especially high-quality varieties, is still low. Even though variety is one of the factors that greatly determines the quantity and quality of agricultural products. A new variety of plants is produced by assembling commonly called plant breeding. Breeding is a process and also produces a product. Plant Breeding Activities (Assembling Plant Varieties) require a very long and long time, sometimes, a certain variety of plants takes 15 years from the start of the plant breeding process until it is ready to be marketed. Protection of Plant Varieties (PVP) is given to plant breeders as a tribute to their efforts in producing new plant varieties that provide benefits to the broad agricultural sector based on Law Number 29 of 2000 concerning Plant Variety Protection.[2]

Provision of Plant Variety Protection is a guarantee for plant varieties produced by breeders (breeders) so that the crop varieties they produce are not stolen by others. In addition, the existence of this PVP system causes the research and development activities of new plant varieties to grow faster.[1]

The existence of the Protection of Plant Varieties (PVP) is possible for farmers, breeders, seed entrepreneurs to be open to each other in terms of accessing germplasm sources from around the world. Germplasm (genetic resources) is the body part of plants, animals, or microorganisms that have the function and ability to inherit traits, so that the development of the agricultural world will be more advanced and developed.

Elucidation of Article 10 of Law Number 29 of 2000 concerning Protection of Plant Variety Protection states that basically, the law is drafted to create clear and firm laws in providing legal protection for breeders' rights, and also to create a climate conducive to the development of activities plant breeding. Protection of breeder's rights is given while taking into account the farmer's privilege to be able to reuse some of the yield (seed) of protected plant varieties for replanting in the next planting season, as long as the use is not for commercial purposes.

Therefore, it can get revealed that everything that is done in order to produce new plants cannot be separated from the goal of meeting farmers' needs for quality seeds. However, in reality, the farmers still lack the privileges they have. We can see through the Nganjuk District Court verdict that sentenced him to six months in prison and one-year probation may not plant corn and a fine of Rp 200 thousand against a farmer named Tukirin. The sentence was handed down by the Assembly on the basis of illegal certification of seed patents owned by PT Benih Inti Subur Tani (BISI), which was carried out by Tukirin.

The Assembly is of the opinion that Tukirin has violated Article 61 paragraph 1 (b) jo. Article 14 paragraph 1 of Law No. 12 of 1992 concerning Plant Cultivation Systems.[3] Ironically, Tukirin, who is blind to the law, apparently never carried out any certification, it is known that in fact Tukirin is a creative farmer who succeeded in innovating the way of cultivating corn by crossing between corn plants and one of the crossed seeds is a seed that has been patented by producing it. PT BISI.

Based on the case of Tukirin, we might think whether it is indeed due to the lack of understanding of law enforcement officials regarding the provisions of Law Number 29 of 2000 concerning Plant Variety Protection or even the provisions of Law Number 29 of 2000 concerning Plant Variety Protection which is unclear in regulating Protection against Breeder and Farmer, proven by not using the provisions of the law in deciding the case at all.

The problems are formulated as follows:

1. How is the protection of plant breeders rights stipulated in Law No.29 of 2000 concerning Plant Variety Protection? 
2. Are the provisions of Law No.29 of 2000 concerning the Legal Protection of Indonesian Plant Varieties already accommodating in relation to legal protection of Farmers' Rights?

\section{Method}

The method of approach used in this study is a normative juridical approach. The research specification to be used is analytical descriptive. Data collection is called secondary data.

\section{Research Results and Discussion}

\subsection{Overview of Plant Variety Protection}

\subsubsection{History of Plant Variety Protection}

Protection of Plant Varieties is a provision in IPR that is still relatively new in the history of its protection as an immaterial right granted to individuals by the state. In other countries, such as the United States, although not specifically written in the regulations of the country, it is well known for the existence of regulations concerning protection of plant varieties. The regulation came into force in 1930 in conjunction with the publication of The United States Patent Act 1930. And in Europe, laws relating to the protection of plant varieties and their results have been known since the 16th century.

In 1961, several countries in the world agreed on an international convention on the protection of plant varieties, an international agreement contained in the International Convention for the Protection of New Varieties of Plants, better known as UPOV. UPOV is an acronym for Union International pour la protection des obtentions vegetale. [4] In Indonesia, protection of plant varieties has begun to be regulated since 1989, namely in the regulation of IPR in the field of patents. In the Patent Law of 1989 it is stated that patent protection cannot be granted to food, beverages and plant varieties, especially for rice, maize, cassava and sweet potato commodities. In 1997, the Patent Law was amended in the form of revocation or elimination of the provisions prohibiting the granting of protection for food, beverages and plant varieties. So that in the 1997 Patent Law, food, drinks and plant varieties can obtain protection in the form of patents. [5]

Although the 1997 Patent Law permits the granting of patent protection to plants, the 1997 Patent Law cannot provide comprehensive protection for aspects of new varieties. For this reason, the Government of the Republic of Indonesia made new laws aimed at protecting plant varieties more thoroughly in Law No.29 of 2000 concerning Plant Variety Protection.

\subsubsection{Convention concerning Protection of Plant Varieties}

Almost all countries that regulate Plant Variety Protection are basically based on the norms contained in The International Convention for the Protection of New Varieties of Plants. The convention was formed by European countries on December 2, 1961 which was followed up with the establishment of an institution called the International Union for the Protection of New Varieties of Plants (UPOV). The institution is Independent, international scale, and is an organization between governments as subjects of international law, based in Geneva.[6] 
Regulation of Plant Variety Protection in Indonesia, in addition to being encouraged by the UPOV convention, is also due to the birth of TRIPS (Trade Related Aspects of Intellectual Property Rights). Given that Indonesia is a member of the WTO, Indonesia has an obligation to implement the provisions contained in TRIPS. Other International Conventions relating to the Protection of Plant Varieties, include:

1. International Treaty for Plant Genetic Resources for Food and Agriculture (International Agreement on Plant Genetic Resources for Food and Agriculture).

2. Convention on Biological Diversity.

This International Agreement on Plant Genetic Resources for Food and Agriculture has become an binding agreement for Indonesia since it was ratified as stipulated in Law Number 4 of 2006 concerning Ratification of the International Agreement on Plant Genetic Resources for Food and Agriculture.[7]

The Convention on Biological Diversity is an international agreement on biodiversity with a global and comprehensive scope. This convention aims at the preservation and sustainable use of biodiversity fairly.[6]

\subsection{Legal Protection of Breeders' Rights According to the PVP Law}

\subsubsection{Legal Protection of Breeder Rights outside the PVP Law}

Law Number 29 of 2000 concerning Plant Variety Protection (PVP Law) is one of the legal provisions that provides protection to breeders for the results of their breeding activities, however, before the existence of the PVP Law, it has been accommodated in Law Number 12 of 1992 concerning the System Plant Cultivation (UU SBT). The SBT Act regulates the protection of recognition and appreciation that will be obtained by those who have succeeded in creating a new variety or called a plant breeder.

Article 11 of the SBT Law states "Any person or legal entity can conduct plant breeding to find superior varieties". This provision can encourage enthusiasm for breeders both individuals and legal entities to conduct breeding activities in order to find new plant varieties.

Provisions in Article 55 of the SBT Law regulate awards relating to:

1. To the inventor of the right technology and the theory and new scientific methods in the field of plant cultivation can be given an award by the government.

2. To the inventor of new types and/or superior varieties, can be given an award by the government and has the right to name their findings.

3. Every person or legal entity whose plants have certain advantages can be given an award by the government.

4. Provisions regarding the awarding as referred to in paragraph (1), paragraph (2) and paragraph (3), shall be further regulated by the government.

Article 45 Government Regulation Number 44 of 1995 concerning Plant Germination also regulates the award given to breeders for the varieties they find, as follows:

1. The Minister gives awards to inventors of superior varieties and/or technologies in the field of seed.

2. Further provisions regarding the awarding as referred to in paragraph (1) shall be regulated by the Minister.

Elucidation of Article 45 paragraph (1) of Government Regulation Number 44 of 1995 concerning Plant Breeding states that:[8] 
1. The awarding in this provision does not constitute recognition of ownership rights as in the case of patents or other civil rights.

From the explanation of Article 45 paragraph (1) of Government Regulation Number 44 of 1995 above and article 55 paragraph (2) of the SBT Act which states that, "to discoverers of new types and/or superior varieties, awards can be given by the government and have the right to give names to the findings." it can be revealed that the form of recognition and appreciation given by these provisions is only limited to giving the breeders the right to give names to the new varieties of their findings.

\subsubsection{Legal Protection of Plant Breeders in the PVP Law}

Protection of Plant Breeders in Indonesia was originally regulated in the SBT Act but the SBT Act only stipulates that the Protection of Breeders is limited to the breeder's right to name new varieties of findings. Then in 2000 Indonesia made a more detailed law concerning the Protection of Plant Varieties, namely Law No.29 of 2000 concerning Protection of Plant Varieties. In this PVP Law, the existence of breeders who conduct breeding will be protected or more protected than the previous regulation, anyone who produces varieties of plants that meet the provisions of the PVP Law can obtain PVP rights and get economic benefits from the results of the breeding. In Articles 4, 6, 8, and 42 the PVP Law is also regulated relating to the protection of the rights possessed by beginners.

The provisions of Article 4 paragraph 1 of the PVP Law regulates the period of protection given to breeders for varieties of their findings. Article 4 paragraph 1 of the PVP Law states that:

1. Period of PVP

a. 20 (twenty) years for annual crops;

b. 25 (twenty five) years for annual plants.

The annual crops referred to by the PVP Law are plants for tree species and vines for example rice, sugar cane, tobacco, cotton, potatoes, mushrooms, corn and so on. As for the annual crops referred to in the PVP Law, for example teak, oil palm, rubber, manga, sago and so on.

The provisions contained in Article 4 paragraph 1 of the PVP Law are similar to those contained in the provisions of Article 19 of the 1991 UPOV Convention. The provisions of Article 19 of the 1991 UPOV Convention concerning "duration of the breeder's rights" states that:

1. [Period of protection] The breeder's right shall be granted for a fixed period.

2. [Minimum Period] The said period shall not be shorter than 20 years from the dato of the grant of the breeder's right. For trees and vines, the said period shall not be shorter than 25 years from the said date.

The provisions of Article 19 of the 1991 UPOV Convention can be interpreted that breeders' rights must be granted for a predetermined period of time. The period of time granted must not be less than 20 years since the issuance of breeders' rights (PVP rights), and for trees and vines the period of protection provided cannot be less than 25 years.

The provisions of the UPOV Convention adopted in Law No.29 of 2000 concerning Plant Variety Protection are not binding conditions for Indonesia considering that up to now, Indonesia has not ratified the UPOV Convention, meaning that there is an opportunity for 
Indonesia to draw up legal provisions protection of plant varieties in accordance with national needs, without having to directly adopt the provisions contained in the UPOV Convention.

The PVP Law also mentions various rights possessed by PVP rights holders (Pemulia rights). Article 6 of the PVP Law regulates the right of breeders to give permission to other persons or legal entities to carry out propagation of varieties of their findings. In addition, the provisions of Article 6 of the PVP Law also regulates the rights still attached to breeders when the plants found are used as origin varieties of new varieties developed further (essential derivative varieties).

The provisions of Article 8 of the PVP Law regulates the right of breeders to obtain appropriate compensation from a variety resulting from their breeding activities. This is done by taking into account the economic benefits obtained from these varieties. Article 8 of the PVP Law states that:

1. Breeders who produce varieties as referred to in article 5 paragraph (2) and paragraph (3) are entitled to receive appropriate compensation by taking into account the economic benefits that can be obtained from the verification.

2. The benefits referred to in paragraph (1) may be paid:

a. In a certain amount and at the same time;

b. Based on percentage;

c. In the form of a combination of a certain amount and at the same time with prizes or bonuses; or

d. In the form of a combination of percentages with prizes or bonuses, the amount of which is determined by the parties concerned.

3. The provisions referred to in paragraph (1) do not abolish the breeder's right to keep their names listed in the PVP rights granting certificate. The rewards referred to in the provisions of article 8 of the PVP Law are rewards arising from an employment agreement made between the breeder and another person or legal entity.

Parties to carry out propagation or other activities as stipulated in the provisions of Article 6 paragraph 3 of the PVP Law. In contrast to the transfer of PVP rights regulated in Article 40 of the PVP Law, the rights agreement with this license is bound to certain periods and certain conditions.

The provisions of Article 6, 8, and 42 above show that the scope of protection contained in the PVP Law does not only include the breeder's moral rights but also includes economic rights. In addition to regulating the rights of PVP holders in the PVP Law also regulates several obligations for PVP rights holders contained in Article 9.

Article 9 of the PVP Law stipulates that:

1. PVP rights holders are obliged to:

a. Carry out PVP rights in Indonesia;

b. Pay the annual PVP fee;

c. Provide and show examples of seed varieties that have received PVP rights in Indonesia.

\subsubsection{Transfer of PVP Rights Holder Rights}

Regulations relating to the transfer of PVP rights are contained in Article 40 paragraph (1) which states that:

1. PVP rights can be transferred or transferred because:

a. Inheritance; 

b. Grant;
c. Will;
d. Agreement in the form of a notarial deed; or
e. Another reason justified by law.

The transfer of protection rights for plant varieties must be accompanied by other Plant Variety Protection documents related to it. Every transfer of Plant Variety Protection Rights must be recorded at the Office of Plant Variety Protection and recorded in the General Register of Plant Variety Protection by paying a fee the amount determined by the Minister of Agriculture.[6] The transfer of Plant Variety Protection Right does not erase the Breeder's right to keep the name and other identities included in the Plant Variety Protection Right Certificate.[6]

\subsubsection{Exclusive rights owned by Breeders or PVP Rights holders}

As explained in the previous points, it can be revealed that the form of respect for breeders' rights as stipulated in the provisions of Article 55 of the WNB Law and Article 45 paragraph 1 of Government Regulation No.44 of 1995 concerning Hatcheries, does not regulate and recognize the rights breeder's ownership of the variety of his findings. As a result, the economic rights held by breeders related to the plant varieties found are not protected. This can be seen by the absence of provisions governing sanctions for the use of plant varieties for propagation or commercial purposes without the approval or permission and inventor (breeder).

Unlike the PVP Law, seen in the preamble number d the PVP Law states "that in order to further increase the interest and participation of individuals and legal entities to carry out plant breeding activities in order to produce new superior varieties, plant breeders or holders of Plant Variety Protection rights need to be granted certain rights and adequate legal protection of these rights. " The concept of respect and legal protection contained in the PVP Law covers the provision of legal protection for intellectual property in producing crop varieties, including the right to enjoy economic benefits and other rights.

It is known that breeding high quality superior varieties requires large investments, both in terms of energy (mind, intellect), labor, material resources, funds, and patience, as well as perseverance, and these efforts can take quite a long time, many years (10-15 years on many species of plants). Once the superior quality varieties are released, these varieties can be immediately multiplied by other parties, thereby robbing the profit opportunities of their beginners who have mobilized large investments. [9]

Granting exclusive rights to a breeder who produces a superior quality variety to exploit his findings, will encourage breeders or seed industry institutions that employ breeders, to invest in breeding activities and will contribute greatly to the development of agriculture, as a whole, increasing farmer's income, prospering society at large.[6]

Robert M. Sherwood's Theory is Economic Growth Stimulus Theory. This theory recognizes that protection of intellectual property rights is a tool of economic development, in the form of the overall objective of establishing an effective protection system for intellectual property rights.

The law gives exclusive rights to a breeder who produces a superior quality variety to exploit his findings, will encourage breeders or seed industry institutions that employ breeders, to invest in breeding activities and will contribute greatly to agricultural development. 
This background of thought is the core foundation why a new high quality variety must be protected in the form of PVP rights as stipulated in Law No.29 of 2000 concerning Plant Variety Protection, with the main objective being to develop and develop a national seed industry in anticipation of the globalization era (open competition), national food problems, population, employment and community income at large, as well as the utilization of national biological resources.[6] However, the exclusive nature of breeders' rights is not full because there are restrictions that are also regulated in the PVP Law.

The provisions of Article 10 paragraph (1) of the PVP Law states that:

1. Not considered a violation of PVP rights, if:

a. Using part of the harvest from protected varieties, as long as not for commercial purposes;

b. Using protected varieties for research, plant breeding, and assembly of new varieties;

c. Using by the Government of protected varieties in the context of food and drug procurement policies with due regard to the economic rights of PVP rights holders.

Application and implementation turns out that breeding is still very little, especially those carried out by farmers. Although the law gives exclusive rights to a breeder who produces a superior variety of quality to exploit these findings. [10]

The difference between Law No.12 of 1992 concerning Plant Cultivation Systems (UU SBT) and Law No.29 of 2000 concerning Protection of Plant Varieties (UU PVT) is the protection of economic rights held by breeders. The SBT Act does not provide protection for economic rights held by breeders, but provides protection for breeders' moral rights. Whereas the PVP Law was drafted as an effort to provide legal protection for breeder's intellectual property in producing crop varieties, including the right to enjoy economic benefits and other rights while taking into account the farmers' privileges.

\subsection{Legal Protection of Farmers' Rights under the PVP Law}

As explained earlier, that the PVP Law was prepared by taking into account the farmers' privileges. However, if we refer to the considerations of the PVP Law, it is seen that the legislators only focus on providing protection to plant breeders in general without giving special protection to farmers. The clauses in the preamble also did not discuss at all related to the protection of farmers' rights.

Then looking at the contents of the law, the existing articles prioritize exclusive protection of plant breeders. Though the possibility of plant breeders registering new varieties is very small considering the complex and expensive registration rules. The regulation applies to individuals and legal entities that wish to register new varieties.[11]

Article 7 paragraph (1) states that "Local varieties belonging to the community are controlled by the State". This provision means that local varieties are varieties that have already existed and are cultivated down by the farmers, as well as belonging to the community and controlled by the state. With this provision, farmers can use the variety without paying because the variety basically belongs to the farmers whose authority is carried out by the state. Then Article 10 paragraph (1) contains exceptions in violation of Plant Variety Protection rights. These provisions provide a loophole for plant breeders to use seeds that have been protected with the condition that the use is not done for commercial purposes and their use for research, plant breeding, and assembly of new varieties. 
Then in the explanation of Article 10 paragraph (1) point a, it states that:

"What is meant by not for commercial purposes is individual activities especially small farmers for their own needs and does not include disseminating activities for the needs of their groups. This needs to be emphasized so that the market share for varieties with PVP is maintained and the interests of PVP rights holders are not harmed."

Provisions regarding farmers' privileges in the provision of Article 10 paragraph 1 point a of the PVP Law aims to protect the rights of small farmers to save part of the harvest (seeds) of protected plant varieties for reuse in the next planting season. However, this category of "small farmers" who obtain farmers 'privileges (farmer' s privilege) is not regulated in the PVP Law.

The absence of a definition of "small farmers" who can obtain farmers' privileges (farmer's privilege) can create multiple interpretations and legal uncertainties in their implementation. Without the provisions governing the category of farmers who can obtain farmers' privileges (farmer's privilege), farmers will be very vulnerable to charges of propagation that are prohibited by law or illegal certification and this will be very detrimental to farmers. However, not regulating the category of smallholders who have farmers' privileges in the PVP Law will also be very detrimental to breeders, because with no classification and a clear definition of smallholders, farmers who have extensive agricultural land including agroindustry entrepreneurs can participate in enjoying the farmer's privileges.

The PVP Law itself basically needs to include provisions relating to the classification of farmers who have the privilege to replant seeds from varieties of plants that have PVP rights for the next planting season. However, the limitation of the category of farmers who can enjoy the privileges of farmers is not intended to hinder the practices of other farmers who are included in the farmers' rights (farmer's rights) such as the right to exchange and sell seeds/propagation material from their own crops.

Based on the description above, it can be concluded that the PVP Law needs to include provisions regarding the category of small farmers who can have farmer privileges.

In addition to the definition of "smallholders", the terms "not for commercial purposes" and "for their own purposes" used in the Elucidation of Article 10 paragraph (1) point a can also be interpreted as restrictions on the activities of farmers to sell or restrictions on the activities of farmers to sell or commercialize the final crop varieties (harvest) that are protected from the plants they plant themselves.

Meanwhile, in the habit that has been carried out for centuries, such as the habit of exchanging seeds, and selling seeds among peasants who are not protected in the PVP Law. In fact, the habits that have been going on for years or even centuries also provide several types of plant varieties that exist today.

With the ratification of the International Treaty on Plant Genetic Resources for Food and Agriculture through Law No.4 of 2006 concerning the Ratification of the International Treaty on Plant Genetic Resources for Food and Agriculture (the Agreement on Plant Genetic Resources for Food and Agriculture), Indonesia has granted recognition of farmers 'rights (farmer's rights) defined as "Farmers' Rights mean rights arising from the past, present future contributions of farmer's in conserving, improving, and making available plant genetic resources, particularly those in the centers of origin/diversity".[7] Farmers' rights can be interpreted as rights arising from past, present and future contributions from farmers to conserve enhance and make available genetic resources for plants, especially those at the center of plant diversity. 
Based on the description above, it can be concluded that the PVP Law needs to be revised by including provisions on the protection of farmers' rights (farmer's rights) that provide guarantees to farmers to continue to carry out existing customs or culture for centuries. This is in line with the provisions contained in Article 9 of Law No.4 of 2006 concerning Ratification of the International Treaty on Plant Genetic Resources for Food and Agriculture.

In addition to the farmers' right the PVP Law also needs to be revised by regulating the right of farmers to get compensation when the varieties of plants protected by PVP rights do not show superior characteristics as promised. This revision is also intended to provide clear, firm, and balanced legal protection to breeders' rights as well as farmer's rights.

\section{Conclusion}

Based on research that has been done as explained in previous chapters, it can be concluded as follows:

1. Provisions in Law No.29 of 2000 concerning Plant Variety Protection have governed the Economic Rights of Plant Breeders. However, the provisions of Law No.29 of 2000 concerning Plant Variety Protection provide unequal treatment between the rights of Breeders and Farmers' rights, such as the absence of explicit provisions related to the rights of farmers while the rights of breeders are very clearly regulated.

2. Law No.29 of 2000 concerning Plant Variety Protection provides only a little protection to farmers and its regulation is implicit in nature so that it creates uncertainty in its enforcement. 


\section{References}

[1] A. Krisnawati and G. Saleh, Perlindungan hukum varietas baru tanaman dalam perspektif hak paten dan hak pemulia. Jakarta: Raja Grafindo Persada, 2004.

[2] Law Number 29 of 2000 concerning Plant Variety Protection. .

[3] Law No. 12 of 1992 concerning Plant Cultivation Systems (UU SBT). .

[4] K. Setyowati, "Pokok-Pokok Peraturan Perlindungan Varietas Tanaman." Jakarta, 2001.

[5] I. B. R. Supancana, Laporan Akhir Tim Pengkajian Hukum tentang Perlindungan Varietas Tanaman Lokal Dalam Hukum Nasional dan Internasional. Jakarta: Badan Pembinaan Hukum Nasional, 2011.

[6] R. Djubaedillah and M. D. Djumhana, Hak Milik Intelektual: sejarah, teori dan prakteknya di Indonesia. Bandung: Citra Aditya Bakti, 2014.

[7] Law Number 4 of 2006 concerning Ratification of the International Agreement on Plant Genetic Resources for Food and Agriculture. .

[8] Government Regulation Number 44 of 1995 concerning Plant Breeding. .

[9] Plantus, "Manfaat dan implementasi UU no. 29 th 2000 tentang PVT dalam pembangunan industri perbenihan," 2008. [Online]. Available: https://anekaplanta.wordpress.com/2008/01/13/manfaat-dan-implementasi-uu-no-29th-2000-tentang-pvt-dalam-pembangunan-industri-perbenihan/. [Accessed: 02-Feb2020].

[10] R. Andria, "Implementasi Perlindungan Varietas Tanaman serta Perlindungan Hukum Bagi Petani atas Pemegang Hak PVT di Indonesia," 2014. [Online]. Available: http://www.law-indonesia.org/2014/01/implementasi-perlindungan-varietas.html. [Accessed: 02-Feb-2020].

[11] I. P. S. Wahyuni, "Upaya Perlindungan Hukum terhadap Hak-Hak Petani Pemulia Tanaman di Indonesia,” Universitas Brawijaya, 2013. 